\title{
Proses pembelajaran dalam komunitas Joglo Tani
}

\author{
Citra Nirmala Dara Yukti *, Sugeng Bayu Wahyono \\ Pascasarjana, Universitas Negeri Yogyakarta. \\ Jalan Colombo No. 1, Karang Malang, Caturtunggal, Sleman, D. I. Yogyakarta 55281, Indonesia. \\ citranirmala77@gmail.com \\ * Corresponding Author
}

\section{ARTICLE INFO}

\section{Article History}

Received:

25 July 2019;

Revised:

22 July 2020;

Accepted:

22 July 2020

\section{Keywords}

Komunitas Joglo Tani; Pedagogi;

Pembelajaran;

Joglo Tani community;

Pedagogy;

Instructional

\begin{abstract}
Penelitian ini bertujuan untuk mengungkapkan pelaksanaan pembelajaran, faktor pendorong dan penghambat, dan petani memaknai proses pembelajaran di Joglo Tani. Penelitian ini menggunakan pendekatan deskriptif kualitatif. Pengumpulan data dilakukan melalui observasi dan wawancara. Keabsahan data menggunakan ketekunan, pengamatan dan triangulasi sumber. Analisis data melalui pencatatan, reduksi, penyajian, dan penarikan kesimpulan. Hasil penelitian menjelaskan berdasarkan skema teknologi pembelajaran mulai dari perencanaan, pelaksanaan dan evaluasi menerapkan prinsip pedagogi kritis. Faktor pendorong yaitu ketersediaan donatur, lingkungan yang asri dan terciptanya suasana belajar yang bersifat kekeluargaan. Faktor penghambat yaitu belum tersedia tersedia internet dan kepercayaan masyarkat masih mengedepankan sekolah formal. Joglo Tani mempertegas posisi fasilitator dan warga belajar sederajat dalam peoses saling belajar.
\end{abstract}

This study aims to reveal the teaching implementation, the supporting and inhibiting factors, and the farmer's interpret the teaching process in Joglo Tani. This study is a descriptive qualitative approach. The data collection was done through interviews and observation. The data validation was through persistence field observation and source triangulation. The data analysis was through the stages of data recording, data reduction, data presentation, and drawing conclusions. This study produced the instructional technology scheme that started from the planning, implementation, and evaluation that applies the principles of critical pedagogy. The supporting factors are the availability of donors, the beautiful environment, and the creation of a family-like learning atmosphere, while the inhibiting factors are the unavailability of the internet service and public trust who prioritize formal school. Joglo Tani reinforces the position of the instructor and participants in an equal position in the process of mutual learning.

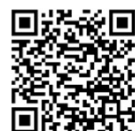

This is an open access article under the $\underline{\mathrm{CC}-\mathrm{BY}-\mathrm{SA}}$ license.

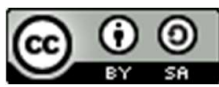

\section{PENDAHULUAN}

Dalam menghadapi era globalisasi, kekuatan dan kesinambungan pembangunan pertanian diukur dari ketangguhan dan kemampuan petani dalam mengelola sumberdaya alam. Petani mandiri adalah petani yang secara dinamis mampu memanfaatkan secara optimal sumberdaya alam, tenaga, modal, dan teknologi yang ada pada lingkungan fisik tempatnya berpijak yang sekaligus mampu meningkatkan kesejahteraannya dalam arti luas. Pengertian ini mencakup kemampuan untuk mengatasi segala tantangan, hambatan, ancaman, dan gangguan terhadap eksistensi serta kelestarian sumberdaya alam. Petani sebagai manajer mandiri yang berpengetahuan, terampil, cakap menilai 
peluang usaha dan dapat mengambil keputusan sendiri untuk bertindak dan mampu untuk selalu menyesuaikan diri terhadap perubahan globalisasi.

Jalan yang diyakini dapat mengatasi permasalahan petani dan membebaskan petani dari kemiskinan adalah melalui pendidikan. Undang-Undang Nomor 20 Tahun 2003 tentang Sistem pendidikan Nasional Pasal 13 Ayat (1) menjelaskan bahwa penyelenggaraan pendidikan dilaksanakan melalui tiga jalur yaitu pendidikan formal, nonformal, dan informal yang saling melengkapi dan memperkaya. Pendidikan nonformal sebagai bagian integral dari pembangunan pendidikan nasional diselenggarakan untuk menunjang upaya peningkatan mutu sumber daya manusia dalam menghadapi berbagai tantangan guna memenuhi kebutuhan belajar masyarakat yang tidak dapat terlayani oleh jalur pendidikan formal. Pendidikan yang paling sesuai untuk petani sebagai orang dewasa adalah pendidikan membebaskan dan bersifat non formal, dengan proses pembelajaran dalam lingkungan usahatani setempat. Karakteristik metode pembelajaran untuk orang dewasa menurut Sudjana $(2005$, p. 7$)$ adalah luwes, terbuka, dan partisipatif. Hal tersebut sejalan dengan pemikiran Freire (1984) yang menghendaki sekolah benar-benar hadir sebagai rumah yang demokratis, damai, dan mendamaikan.

Education as the practice of freedom-as opposed to education as the practice of dominationdenies that man is abstract, isolated, independent, and unattached to the world; it also denies that the world exists as a reality apart from people. Authentic reflektion considers neither abstract man nor the world without people, but people in their relations with the world (Leach, 1982, p. 187).

Berdasarkan pernyataan tersebut, dijelaskan bahwa hubungan yang ideal antara fasilitator dan warga belajar bukanlah hierarkikal sebagaimana dalam banking concept of education, tetapi merupakan hubungan dialogikal. Pembelajaran dialogis adalah konsep pembelajaran yang mempertegas posisi atau peran fasilitator dan warga belajar tidak berada dalam posisi bawah, melainkan setara atau sederajat dalam proses saling belajar. Freire (1984, p. 9) menyebutkan bahwa dalam pelaksanaan pembelajaran perlu menggunakan metode hadap-masalah (problem-solving), dengan memberikan suatu masalah yang belum terpecahkan dan meminta warga belajar untuk menyelesaikannya. Menurut Trianto (2010, p. 94) tujuan pembelajaran berdasarkan masalah dapat membantu siswa mengembangkan keterampilan, belajar peranan orang dewasa yang autentik dan menjadi pembelajar yang mandiri.

Undang-Undang Nomor 20 tahun 2003 tentang Sistem Pendidikan Nasional Pasal 36 Ayat (2) ditegaskan bahwa kurikulum pada semua jenjang dan jenis pendidikan dikembangkan dengan prinsip diversivikasi sesuai dengan satuan pendidikan, potensi daerah dan warga belajar. Oleh karena itu, dalam penyusunan materi belajar harus disesuaikan dengan kebutuhan warga belajar dan kaidah lokalitas masyarakat setempat. Materi belajar berdasar kurikulum yang dikembangkan hendaknya disusun melalui proses keterlibatan warga belajar dan masyarakat secara penuh untuk dapat menemukan materi yang dipelajari dan menghubungkannya dengan situasi kehidupan nyata sehingga mendorong warga belajar untuk dapat menerapkanmya dalam kehidupan nyata mereka. Namun menurut Susanto (2007, p. 6) menyatakan bahwa kurang unggulnya mutu lulusan lembaga pendidikan Indonesia selama ini antara lain dipicu oleh paradigma pendidikan yang masih tradisional (ideology konservatif) yakni pendidikan yang sekedar dipandang sebagai ajang transfer of knowledge dimana masih menggunakan sistem ceramah, anti dialog, hafalan serta dikte yang cenderung bersifat teoritik, proses penjinakan, pewarisan pengetahuan dan tidak bersumber pada suatu realitas masyarakat di tempat warga belajar itu berada.

Hasil pengamatan lain juga dilakukan oleh Supardan (2014) mengenai proses pembelajaran di SMK Pertanian masih terlihat bersifat verbal, komunikasi guru dengan murid masih satu arah (teacher center), sehingga siswa terlihat tidak bersungguh-sungguh dan kurang semangat dalam belajar. Pembelajaran akan menyenangkan jika ada pola hubungan yang baik antara pendidik dan warga belajar dalam proses pembelajaran. Pedidik memposisikan diri sebagai mitra belajar warga belajar, bahkan dalam hal tertentu tidak menutup kemungkinan pendidik belajar dari warga belajar. Dalam hal ini perlu diciptakan suasana yang demokratis dan tidak ada beban (Rusman, 2011, p. 326). Harapan yang ingin dicapai dari pembelajaran yang menyenangkan yaitu untuk membantu warga belajar memiliki pengetahuan, pengalaman dan keterampilan guna meningkatkan kesejahteraan 
dalam kehidupannya. Sepanjang masih terdapat masalah dalam pendidikan, sepanjang itu pula masih dibutuhkan keilmuan teknologi pembelajaran. Permasalahan yang dapat ditemukan di dalam pelaksanaan pembelajaran dapat diteliti sehingga keilmuan teknologi pembelajaran menjadi berkembang, terutama terkait pada pembelajaran yang bersifat satu arah. Oleh karena itu pembelajaran menjadi garapan keilmuan yang penting untuk diteliti.

Fenomena tersebut menjadi gambaran awal untuk melakukan studi mendalam tentang proses pembelajaran dan bagaimana petani memaknai proses pembelajara tersebut. Oleh sebab itu, diperlukan studi terhadap. Subjek studi adalah warga belajar pada usia 18-20 tahun yang sedang melaksanakan pembelajaran penanganan hama padi organik di Joglo Tani. Fokus penelitian dalam penelitian kualitatif ini mengenai proses pembelajaran pada warga belajar. Berdasarkan uraian tersebut, penelitian ini bertujuan mengungkapkan proses pembelajaran penanganan padi organik, faktor pendorong dan penghambat serta cara petani memaknai pembelajaran.

\section{METODE}

Pendekatan penelitian ini adalah kualitatif. Jenis metode penelitian kualitatif yang digunakan adalah deskriptif. Metode deskriptif dapat diartikan sebagai prosedur pemecahan masalah yang diselidiki dengan menggambarkan atau melukiskan keadaan subyek atau obyek penelitian (orang, lembaga, dan masyarakat) pada saat sekarang berdasarkan fakta-fakta yang tampak atau sebagaimana adanya (Nawawi, 2005, p. 63). Selama pengamatan tersebut, peneliti terlibat dalam kegiatan pembelajaran dan mewanwancarai subjek penelitian sehingga peneliti dapat mempelajari pembelajaran di Joglo Tani. Penelitian dilakukan di Joglo Tani dusun Mandungan I, Margoluwih, Seyegan, Sleman. Waktu penelitian selama 6 bulan, mulai dari persiapan, perizinan sampai peneliti mengambil data. Khusus pada pengambilan data memakan waktu selama 4 bulan, yaitu dari rentang bulan Juli 2016 sampai Oktober 2016.

Subjek penelitian ini merupakan informan kunci dan informan. Informan kunci dipilih dengan menggunakan teknik pertimbangan purpotif, yaitu memilih tokoh yang mengetahui dan menyelenggarakan pembelajaran. Informan kunci yang didapat adalah pendiri Joglo Tani. Selanjutnya, informan dipilih secara purpotif atas penunjukkan informan kunci. Mereka adalah satu fasilitator dan satu warga belajar. Wawancara terhadap informan dihentikan apabila data yang diperoleh dipandang sudah memadai, dalam arti sesuai dengan tujuan penelitian.

Peneliti melakukan studi lapangan untuk menentukan fokus penelitian. Pada 21 Februari 2016, peneliti memulai melakukan pra survey untuk menemukan kemungkinan-kemungkinan adanya permasalahan yang ditemui dengan cara mewancarai pendiri Joglo Tani untuk mendapatkan informasi sejarah dan pengelolaan pembelajaran di Joglo Tani. Pada 24 Juli 2016 sampai dengan 23 Oktober 2016, peneliti berpartisipasi dalam pembelajaran, peneliti terlibat dan mengamati lingkungan pembelajaran. Setidaknya setiap satu minggu sekali, peneliti terlibat dan mengamati kegiatan pembelajaran. Peneliti berusaha membangun interaksi dengan para warga belajar selayaknya teman agar mereka bisa terbuka dalam mengungkapkan persepsi sebagai data yang peneliti butuhkan. Peneliti telah mengamati subjek maupun objek penelitian, sesegera mungkin peneliti membuat catatan lapangan. Catatan lapangan dibuat setiap saat menjadi bahan analisis penelitian sehingga peneliti dapat menentukan data apalagi yang harus dicari ataupun diperiksa keabsahannya. Data diperoleh bersumber dari instrumen penelitian yang dikumpulkan dengan teknik observasi dan wawancara. Data penelitian diambil berdasarkan instrumen pengumpulan data, yang terdiri dari lembar observasi dan panduan wawancara informan. Data-data yang dikumpulkan seperti perencanaan pembelajaran, pelaksanaan pembelajaran, evaluasi pembelajaran, faktor pendorong dan penghambat pembelajaran.

Bogdan dan Biklen (dalam Moleong, 2002, p. 248) menjelaskan analisis data kualitatif adalah upaya yang dilakukan dengan jalan bekerja dengan data, mengorganisasikan data, memilahmilahnya menjadi suatu yang dapat dikelola, mencari dan menemukan pola, menemukan apa yang penting dan apa yang dipelajari, dan memutuskan apa yang dapat diceritakan kepada orang lain. Berdasarkan rumusan tersebut digarisbawahi bahwa analisis data dalam hal ini mengatur, mengurutkan, mengelompokkan, memberikan kode dan mengkategorikannya. Proses analisis dimulai dengan menelaah seluruh data yang tersedia dengan berbagai sumber yaitu wawancara, observasi dan 
dokumentasi. Dari hasil perolehan data, maka hasil penelitian dianalisis secara tepat agar simpulan yang diperoleh dapat tepat pula. Proses analisis data memiliki tiga unsur yang dipertimbangkan oleh peneliti yaitu: 1.) Reduksi data. Reduksi dapat diartikan sebagai proses pemilihan, pemusatan perhatian penyederhanaan, pengabstrakan dan transformasi data "kasar" yang muncul dari catatancatatan tertulis dilapangan (Miles \& Huberman, 1992, p. 16); 2.) Penyajian data. Sajian data adalah suatu susunan informasi yang memungkinkan kesimpulan dapat ditarik (Miles \& Huberman, 1992, p. 17). Melihat suatu sajian data, penganalisis akan dapat memahami apa yang terjadi, serta memberikan peluang bagi penganalisis untuk mengerjakan sesuatu pada analisis atau tindakan lain berdasarkan pemahaman tersebut; dan 3.) Penarikan simpulan atau verifikasi. Simpulan akhir dalam proses analisis kualitatif ini tidak akan ditarik kecuali setelah proses pengumpulan data berakhir. Simpulan yang ditarik perlu diverifikasi dengan cara melihat dan mempertanyakan kembali

\section{HASIL DAN PEMBAHASAN}

Perencanaan Pembelajaran

Proses perencanaan pembelajaran Joglo Tani menggunakan model dialogis dengan semangat membebaskan dan menempatkan warga untuk benar-benar belajar dan sebagai aktor utama dalam penentu kebijakan dan keberlangsungan kegiatan belajar. Rencana pembelajaran disusun setiap satu musim dengan menekankan bahwa setiap warga belajar memiliki kebebasan dalam menentukan isi atau topik materi yang ingin dipelajari. Semuanya memegang teguh prinsip bahwa pada hakikatnya warga belajar selaku subyek didik adalah aktor bebas yang unik yang memiliki minat, latar belakang, potensi, bakat, kemampuan yang berbeda-beda yang harus dikembangkan sesuai dengan minat dan kebutuhan.

Penentuan materi atau topik bahasan dalam perencanaan pembelajaran di Joglo Tani dilakukan melalui proses identifikasi atau assessment kebutuhan belajar menggunakan teknik diskusi. Setiap warga belajar memiliki hak untuk menentukan topik materi apa yang akan dipelajari pada awal pertemuan dan disepakati materi mana yang akan dipelajarai terlebih dahulu melalui proses penentuan prioritas kebutuhan belajar. Seperti yang dijelaskan oleh Rifa'i (2008, p. 38) apabila pembelajaran tersebut sesuai dengan kebutuhan, maka warga belajar akan belajar secara optimal yang pada akhirnya akan memperoleh hasil belajar seperti yang diharapkan. Tema yang tidak disepakati, tidak dihapus dari rencana pembelajaran, akan tetap dijadikan sebagai tema belajar selanjutnya dikemudian hari.

Metode perencanaan pembelajaran pada Joglo Tani terdapat istilah Student Learning Center, artinya semua pembelajaran berjalan berdasarkan keinginan warga belajar. Warga belajar ingin belajar apa dan bagaimana semua dikembalikan sesuai dengan kesepakatan bersama. Fungsi fasilitator dalam perencanaan pembelajaran adalah dinamisator. Ketika terjadi sebuah kebekuan di forum yang sedang berlangsung maka fasilitator akan memancing agar warga belajar memberikan masukan atau usulan berkaitan dengan apa yang akan dilakukan berikutnya. Hal ini diperkuat oleh hasil penelitian Mastur (2017. p. 57) mengenai fungsi pendidik dalam palaksanaan pembelajaran sebagai fasilitator dalam memunculkan gagasan baru dengan tujuan memberi keleluasaan kepada siswa dalam mengembangkan sumber belajar, sedangkan selebihnya proses perencanaan lebih menekan-kan pada keaktifan warga belajar sendiri. Hal ini menekankan bahwa keikutsertaan warga belajar untuk memberikan kontribusinya sangat penting dan hal tersebut tidak membuat mereka canggung atau malu untuk mengungkapkan ide kepada teman lain.

Pihak-pihak yang terlibat dalam perencanaan pembelajaran Joglo Tani dibangun menggunakan kaidah lokalitas. Kaidah ini dimaksudkan bahwa komponen terpadu warga belajar, fasilitator, pengelola, orangtua, dan masyarakat saling bekerja sama dan salaing berpartisipasi aktif dalam wadah sistem persahabatan. Bagi yang memiliki pengalaman yang memadahi dijadikan sebagai pengelola Joglo Tani. Joglo Tani adalah tempat laboratorium untuk belajar, sebagai penyedia pengetahuan luas tanpa tergantung pada ketersediaan dan fasilitas. Ada atau tidaknya media pembelajaran tidak menjadi penghalang bagi keberlangsungan proses pembelajaran bagi warga belajar di Joglo Tani. Joglo Tani memiliki keterdekatan yang erat dengan masyarakat dan alam dengan seoptimal mungkin dimanfaatkan dengan segala potensi yang ada sebagai media belajar. Hal 
tersebut sesuai dengan Undang-Undang Republik Indonesia Nomor 20 tahun 2003 tentang Sistem Pendidikan Nasional Pasal 4 Ayat (6) yang berbunyi bahwa pendidikan diselenggarakan dengan memberdayakan semua komponen masyarakat melalui peran serta dalam penyelenggaraan dan pengendalian mutu layanan pendidikan. Kemudian pada Pasal 8 dan 9 Undang-Undang Republik Indonesia Nomor 20 tahun 2003 tentang Sistem Pendidikan Nasional juga menerangkan hak dan kewajiban masyarakat dalam penyelenggaraan pendidikan, serta berkewajiban memberikan dukungan sumber daya dalam penyelenggaraan pendidikan.

Prinsip membebaskan dalam pelaksanaan pembelajaran pada Joglo Tani ditunjukkan dengan tidak adanya seragam, tata tertib dan jadwal mata pelajaran tetap, yang ada hanya jadwal waktu belajar. Selain itu waktu dan tempat belajar di Joglo Tani berdasarkan pada kesepakatan antara warga belajar dan fasilitator, apabila warga belajar dan fasilitator sepakat, maka pembelajaran bisa dilaksanakan di sawah maupun di pendopo. Hal inilah yang menjadi prinsip dari Joglo Tani bahwa belajar pada dasarnya pada lahan terbuka tanpa adanya dinding pemisah. Metode pembelajaran yang digunakan pada Joglo Tani direalisasikan menggunakan metode problemsolving (hadap masalah).

\section{Pelaksanaan Pembelajaran}

Proses pelaksanaan pembelajaran selalu ditanamkan bahwa pembelajaran adalah proses penanaman pemahaman peserta didik bukan hafalan-hafalan dengan menelan proses penyaluran informasi secara mentah-mentah. Pemilihan materi belajar dilakukan berdasarkan kebutuhan yang akan dipelajari. Situasi yang disediakan adalah problemsolving bebas. Warga belajar tidak diberikan suatu informasi yang harus dipatuhi, namun warga belajar diberi kesempatan seluas-luasnya untuk mengajukan masalah sesuai dengan materi apa yang telah disepakati bersama sebelumnya (problematik), kemudian warga belajar diberi waktu untuk menemukan sendiri (inquiry atau discovery) mengenai jawaban dari permasalahan atau soal yang ada melalui buku, pengalaman, internet, dan sumber-sumber belajar lain.

Sesuai dengan hasil temuan penelitian yang dilakukan oleh Artapati dan Budiningsih (2017) bahwa siswa diberi kesempatan menalar agar terciptanya sesi tanya jawab untuk menyimpulkan hasil diskusi yang telah dilakukan. Kegiatan mengkomunikasikan tersebut melatih peserta didik dalam menyampaikan ide, gagasan, dan informasi yang dimilikinya. Komunikasi dapat melatih peserta didik agar dapat mengembangkan kemampuan mereka dalam menyampaikan ide dan pendapat, serta meningkatan kepercayaan diri saat menampilkan tugas di depan peserta didik lainnya. Tahap selanjutnya adalah semua pendapat warga belajar ditampung tanpa mempermasalahkan benar atau salahnya jawaban (brainstorming). Setelah semua menemukan jawabannya masing-masing, warga belajar berdiskusi atau saling melakukan sharing untuk menemukan kesepakatan jawaban yang paling tepat dari masa-lah yang dimunculkan di awal. Hal tersebut dimaksudkan agar dari berbagai ide-ide yang mereka temukan, dapat ditemukan satu struktur yang integratif dari pengetahuan yang sedang dipelajari.

Terlahir sebagai sekolah alternatif, fasilitator memerankan sebagai teman dan sahabat dalam mendampingi peserta didik untuk memperoleh informasi pembelajaran, tidak ada hubungan vertikal diantara keduanya, dan juga tidak ada dikotomi guru dan siswa, semuanya adalah orang yang berkemauan untuk belajar. Suasana tersebut membangun kemandirian dan percaya diri yang besar bagi warga belajar karena mereka terbiasa memutuskan dan menentukan sendiri apa yang mereka butuhkan. Joglo Tani menerapkan pembelajaran yang menyenangkan, dinamis, tidak monoton dan setiap saat memungkinkan munculnya suatu hal yang baru. Semua peraturan sudah menjadi kesepakatan bersama, maka fasilitator tidak bertindak melewati batas kewenangannya yaitu memarahi apalagi harus menghukum.

\section{Evaluasi Pembelajaran}

Evaluasi pembelajaran pada Joglo Tani dilaksanakan dalam bentuk self evaluating atau evaluasi diri, yaitu pandangan dan sikap warga belajar terhadap dirinya untuk menentukan dan mengarahkan konsep diri dalam mengenal bakat, kelemahan, kepandaian dan kegagalannya. Fasilitator bersama dengan warga belajar melakukan dialog untuk membangun konsep yang berkenaan dengan apa yang telah mereka ketahui dan yang belum mereka ketahui, apa yang telah mereka 
lakukan dan kesulitan apa yang mereka hadapi. Siapa yang sudah paham dapat membantu teman yang kurang paham, maka dengan sendirinya akan terjadi saling mengevaluasi antar teman. Konsep inilah yang mempengaruhi penafsiran pengalaman yang telah diperoleh. Tidak ada yang lebih pintar dari yang lain, karena kepintaran masing-masing diukur oleh dirinya sendiri. Hal tersebut sesuai dengan penuturan Bahruddin (2007, p. 89) yang menyebutkan bahwa sistem evaluasi hendaknya berpusat pada subjek didik, yaitu berkemampuan mengevaluasi diri, sehingga tahu persis potensi yang dimilikinya, dan berikut mengembangkannya, sehingga bermanfaat bagi yang lain.

Evaluasi pada Joglo Tani tidak mengenal jenis evaluasi sumatif dalam bentuk ujian baik mid semester maupun akhir semester. Penghargaan pada warga belajar tidak didasarkan pada nilai-nilai yang diciptakan, karena keberhasilan dan kesuksesan yang mereka raih tidak diukur malalui raport dan ranking, namun lebih pada penghargaan secara positif dan total yang didasarkan pada pengakuan atas keberadaan diri mereka. Kecerdasan warga belajar tidak diukur dengan nilai (kecerdasan intelektual) tapi sejauh mana tingkat emosional dan kecerdasan religinya atau spiritualnya, sehingga muncul semangat kebersamaan. Persaingan pun tak lagi berupa persaingan yang saling menjatuhkan. Kualitas warga belajar tidak diukur dengan membandingkan satu dengan yang lain, tetapi dari bertambahnya pengetahuan yang dimiliki. Kepercayaan diri warga belajar selaku subyek didik dipupuk setiap hari. Fasilitator tidak menghakimi kekurangan dan menilai warga belajar itu pintar dan bodoh. Oleh karena itu, secara tidak langsung kepercayaan diri warga belajar dan keberanian untuk melakukan inovasi-inovasi akan tumbuh melalui proses belajar mandiri.

Indikator keberhasilan pencapaian belajar warga dinilai melalui sejauh mana ketercapaian target yang telah dibuat. Pasal 54 ayat 2 Undang - Undang Republik Indonesia tentang Sistem Pendidikan Nasional menyebutkan bahwa masyarakat dapat berperan serta sebagai sumber, pelaksana, dan pengguna hasil pendidikan. Data hasil observasi yang peneliti dapatkan adalah warga belajar telah berhasil dalam penanganan hama padi untuk meningkatkan produktivitasnya. Mereka mempunyai pengalaman dan keterampilan yang dapat digunakan langsung oleh diri mereka sendiri maupun orang lain sebagai jawaban atas permasalahan kehidupan yang terjadi di lingkungan masyarakat antara lain pupuk kompos sebagai jawaban dari permasalahan menekan biaya pengeluaran. Selain itu warga belajar mendapatkan pengalaman cara menanam padi organik yang dimulai dari pengolahan lahan, pembibitan, penanaman padi, penangan hama hingga panen tiba.

Faktor Pendorong dan Penghambat Pembelajaran

Faktor pendukung pembelajaran dialogis pada Joglo Tani salah satunya adalah ketersediaanya peminjam modal maupun donatur untuk menambah penghasilan Joglo Tani maupun masyarakat sekitar. Lingkungan Joglo Tani berada di lingkungan desa dengan suasana asri, sejuk dan tentram. Motivasi dan kemandirian yang tinggi dari warga belajar dengan segala kegketerbatasan dengan tidak bergantung pada siapun. Suasana yang diselimuti rasa persahabatan dan kekeluargaan menjadikan pembelajaraan berjalan dinamis. Faktor penghambat pembelajaran yaitu 1.) Joglo Tani belum dilengkapi dengan jaringan internet; 2.) Terdapat warga belajar satu orang yang tidak serius dalam mengikuti proses pembelajaran, sehingga menjadi kendala dalam keberlangsungan pembelajaran; dan 3.) Masyarakat mempercayai seseorang dapat dikatakan pandai apabila menimba ilmu pada sekolah formal dan mendapatkan ijazah.

\section{Petani Memaknai Pembelajaran di Joglo Tani}

Hasil penelitian yang dilakukan oleh peneliti menunjukkan adanya beberapa manfaat yang dapat dirasakan oleh warga belajar saat melakukan proses pembelajaran mulai dari awal pertemuan hingga akhir pertemuan. Pertama, warga belajar memiliki keterampilan untuk bekal usaha taninya sendiri. Hal ini ditunjukkan karena warga mengalami pembelajaran penanganan hama padi organik guna meningkatkan hasil panen pada musim kemarau yang dilakukan mulai dari fase penyiapan lahan, fase penyiapan bibit, fase penyiapan pemupukan, fase pengolahan tanah, pemupukan dasar, fase penanaman, hingga fase pengamatan. Warga belajar tidak langsung dihadapkan langsung mengenai penanganan hama tetapi warga belajar diberikan pemahaman untuk mengalami pembe- 
lajaran mulai dari fase menyiapan lahan hingga fase pengamatan. Hal tersebut bertujuan agar warga belajar mendapatkan pengalaman lebih dalam menanam padi organik, sehingga mereka dibekali dengan keterampilan mengolah lahan usaha. Pencapaian yang didapatkan warga belajar saat selesai mengikuti pembelajaran tersebut adalah warga belajar dapat menerapkan pengalamannya untuk mengolah lahan usahanya sendiri yang berdampak pada terciptanya lapangan pekerjaan bagi dirinya.

Kedua, penggunaan metode diskusi dalam pembelajaran dapat menghidupkan suasana belajar yang tidak kaku. Belajar menjadi mudah dan menyenangkan karena warga belajar mendapatkan pengetahuan dengan cara bertukar pendapat. Berdiskusi mengandung pembebasan dalam berdialog untuk mengutarakan gagasan. Pembebasan berpendapat merupakan proses humanisasi, bukan semacam tabungan tempat menyimpan informasi. Oleh karena itu, warga belajar diberi kesempatan untuk mengeluarkan informasi pada dirinya agar didengar terhadap orang lain.

Ketiga, warga belajar dapat mengembangkan relasinya, menumbuhkan rasa gotong royong dan menghargai antara sesama dengan adanya kerjasama dalam kelompok belajar. Pelaksanaan pembelajaran dibagi menjadi 5 kelompok agar tidak ada lagi sekat-sekat dalam proses pembelajaran, dan juga tidak perlu adanya dikotomi antara guru dan warga belajar karena semuanya adalah orang yang berkemauan untuk belajar. Sesuai dengan pendapat Bahruddin (2007, pp. 8-9) dengan adanya kerjasama, tidak ada lagi sekat-sekat dalam proses pembelajaran, juga tidak perlu ada dikotomi guru dan warga belajar, semuanya adalah orang yang berkemauan untuk belajar. Manfaat kerja kelompok selain mempermudah pekerjaan juga agar mengembangkan dialog antar sesama warga belajar. Mereka dapat berbagi pengalaman maupun idenya. Dalam suatu kelompok memiliki pembagian tugas, sehingga menumbuhkan rasa gotong royong untuk memajukan kelompoknya.

Keempat, Joglo Tani melakukan pengawasan dan controlling yang disebut dengan ICS (Internal Control System) yang diserahkan langsung kepada warga belajar. Saat warga belajar ada yang melakukan kesalahan ataupun kurang tepat saat pelaksanaan praktik menanam padi, maka warga belajar lain yang sudah bisa dapat mengajarkan kepada warga belajar lainnya yang belum memahami prosesnya. Peran fasilitator mengamati juga sesekali membantu warga belajar yang belum bisa cara menanam padi. Warga belajar dapat saling memberi masukan dan apabila terdapat kesulitan di lahan atau ada masalah dalam berusahatani organik, maka hal tersebut dikonsultasikan kepada fasilitator. Selanjutnya fasilitator memberikan masukan dan solusi untuk masalah tersebut.

Kelima, warga belajar diposisikan dirinya sebagai subyek pembelajaran karena Joglo Tani memberikan peluang bagi warga belajar untuk merencanakan, melaksanakan, dan mengevaluasi pembelajaran dari warga belajar itu sendiri. Fasilitator melakukan pendampingan berupa memberian saran dan arahan kepada warga belajar terkait dengan pembagian kerja, pembagian unit kecil dan pembagian garis kewenangan. Manfaat yang dapat dirasakan warga belajar yaitu diberikannya kesempatan bagi setiap warga belajar dalam memberikan keputusan untuk memilih berbagai keadaan dalam pengorganisasian proses pembelajaran.

\section{SIMPULAN}

Joglo Tani menjadi salah satu pendidikan alternatif dengan mengimplementasikan pembelajaran kritis yaitu 1.) Perencanaan pembelajaran dilaksanakan berdasarkan pada kesepakatan peserta dan pemandu, peserta memiliki kebebasan dalam menentukan tempat, materi dan media pembelajaran, fungsi pemandu sebagai dinamisator layaknya teman bagi peserta; 2.) Pelaksanaan pembelajaran menggunakan strategi student learning center dengan metode pembelajaran menggunakan metode problem solving, suasana belajar yang disediakan bebas dari ancaman dan menggembirakan, alam dan masyarakat merupakan laboratorium dan sumber belajar bagi peserta; dan 3.) Evaluasi belajar menggunakan teknik self-evaluating. Joglo Tani memiliki faktor pendorong dan penghambat pelaksanaan pembelajaran, adapun faktor pendorong yaitu ketersediaannya donatur, lingkungan yang asri, dan terciptanya suasana belajar yang kekeluargaan, sedangkan faktor penghambat pembelajaran yaitu belum tersedianya layananan internet, terdapat peserta yang tidak serius dalam mengikuti proses belajar mengajar, dan kepercayaan masyarakat yang lebih mengedepankan sekolah formal. Joglo Tani memberi peluang bagi peserta sebagai subjek pembelajaran dan mempertegas posisi pemandu dan peserta sederajat dalam proses saling belajar, 
sehingga peserta merasa diberi peluang untuk memecahkan masalah nyata secara historis sebagai negara agraris.

\section{DAFTAR PUSTAKA}

Artapati, L. W., \& Budiningsih, C. A. (2017). Pelaksanaan pembelajaran kurikulum 2013 di SD Negeri Serayu Yogyakarta. Jurnal Inovasi Teknologi Pendidikan, 4(2), 185-200. doi:https://doi.org/10.21831/jitp.v4i2.13016

Bahruddin, A. (2007). Pendidikan alternatif Qaryah Thayyibah. Yogyakarta: LKIS Yogyakarta.

Freire, P. (1984). Pedagogi hati. Yogyakarta: LKIS Yogyakarta.

Miles, B.M., \& Huberman, A. M. (1992). Analisis data kualitatif: Buku sumber tentang metodemetode baru. Jakarta: UI Pers

Leach, T. (1982). Paulo Freire: dialogue, politics, and relevance. International Journal of Lifelong Education, 1(3), 185-201. doi:https://doi.org/10.1080/0260137820010302

Mastur, M. (2017). Implementasi Kurikulum 2013 dalam pelaksanaan pembelajaran di SMP. Jurnal Inovasi Teknologi Pendidikan, 4(1), 50-64. doi:https://doi.org/10.21831/jitp.v4i1.10131

Moleong, L. (2000). Metodologi penelitian kualitatif. Bandung: PT Remaja.

Nawawi, H. (2005). Metode penelitian bidang sosial. Yogyakarta: GMUP.

Presiden Republik Indonesia. (2003). Undang-Undang Nomor 20, Tahun 2003, tentang Sistem Pendidikan Nasional.

Rusman, R. (2011). Model-model pembelajaran (Mengembangkan profesionalisme guru). Jakarta: Rajawali.

Sudjana, S. (2000). Pengembangan pembelajaran pendidikan luar sekolah. Bandung: Falah Production.

Supardan, D. V. (2013). Hubungan sikap dan minat belajar siswa dengan kreativitas siswa SMK kompetensi Agribisnis Tanaman Pangan dan Holtikultura (Unpublished bachelor's thesis). Universitas Pendidikan Indonesia, Jawa Barat.

Susanto, A. (2008). Penerapan metode dialogis versi Paulo Freire (Studi kasus pada SLTP alternatif Qaryah Thayyibah desa Kalibening, Salatiga, Jawa Tengah) (Unpublished bachelor's thesis). Universitas Negeri Malang, Jawa Timur.

Trianto, T. (2010). Mendesain model pembelajaran inovatif-progresif. Jakarta: Bumi Aksara. 